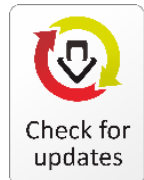

updates

Article Type: Research Paper

\title{
Accounting Student's Moral Judgment and Integrated Cultural Religious-Based Ethics Concept
}

\author{
Made Aristia Prayudi* and I Putu Hendra Martadinata
}

\begin{abstract}
:
Research aims: Despite its widely recognized importance, there is a lack of today's business ethics education regarding the method used for teaching ethics to college students. The conventional business ethics courses are criticized for applying learning approaches limited to the abstract, impersonal moral logic of secular ethics that is less natural, meaningful, and motivating, which cannot have a significant and lasting impact on the moral judgment of its graduates. This current study addresses the issue by investigating the effect of integrating cultural and religious-based ethics concept, named Tri Kaya Parisudha (the Three Holy Deeds - think good, speak good, and do good) into ethical training toward moral judgment development of accounting students.

Design/Methodology/Approach: Data were collected from 46 accounting undergraduate students of a large public university in Bali Province of Indonesia by conducting Pre-test-Post-test Control Group experimental design.

Research findings: The results showed that participants who were receiving ethical training integrate with the Tri Kaya Parisudha concept (treatment group) exhibited higher moral judgment development (that is, have significantly higher DIT p-score) than those who did not (control group). Besides, there was evidence of a statistically significant increasing DIT p-score in the treatment group from pre to post-test, but not in the control group.

Theoretical contribution/Originality: This research contributes to the development of academic studies on Tri Kaya Parisudha and its integration to ethical learning on the development of students' morality.

Practitioner/Policy implication: The results of this study indicate the importance of integrating the value of local wisdom and religiosity values into ethical learning at universities to improve students' morality.

Research limitation/Implication: Although this study found that ethical education at the college level will be more effective if the aspect of religiosity is included within the education process, there are some limitations of this study. First, this study used an experimental method using cases that did not reflect the actual condition and have not been sufficiently related to ethical cases occurring in the business world. Secondly, this study has not been able to fully capture the influence of Tri Kaya Parisudha on students' behavior. Thirdly, this research did not consider another demographic variable that could affect students' moral judgment.

Keywords: Moral judgment; Accounting Student; Business ethics Sducation; Tri Kaya Parisudha
\end{abstract}

Department of Accounting, Universitas Pendidikan Ganesha, Bali, Indonesia

*CORRESPONDENCE:

prayudi.acc@undiksha.ac.id

THIS ARTICLE IS AVALILABLE IN:

http://journal.umy.ac.id/index.php/ai

DOI: 10.18196/jai.2101143 


\section{Introduction}

Call and demand to solve the problem of ethics in business is now prominently increasing following the widely publicized accounting scandals of many world's large corporations (Floyd, Xu, Atkins, \& Caldwell, 2013), as well as in the context of public sector organizations (Aini, Prayudi, \& Diatmika, 2018; Andriana \& Widaningsih, 2014; Thomson, 2014). The solution-seeking efforts are not only done through a series of scholarly and academic research but have also focused on strengthening the strategic role of higher education institutions in internalizing ethical values and social responsibility to its learners (Bean \& Bernardi, 2007; Brinkmann \& Peattie, 2005; Dellaportas, Jackling, Leung, \& Cooper, 2011; Mayhew \& Murphy, 2009; Saat, Porter, \& Woodbine, 2009). Academic scholars (e.g., Adkins \& Radtke, 2004; Cameron \& O'Leary, 2015; D. Christensen, Barnes, \& Rees, 2007; Sims \& Felton, 2006; Warnell, 2010) acknowledge that it is the methodologies employed in a business ethics course that plays an essential role in running business ethics education if it wants to be successful. However, the majority of conventional business ethics courses seem to apply learning approaches limited to the abstract, impersonal moral logic of secular ethics (Cassidy, 2006). As a consequence, students learn theories of business ethics as one more set of abstractions that could not have a significant and lasting impact on their moral judgment.

McCann (1997) advocates considering student's religious experiences when teaching ethics for the sake of inspiring an emotional understanding. By doing so, it is believed that students will have the opportunity to approach business ethics in a context that is more natural, meaningful, and motivating. Epstein (2002) notes that religions offer a unique approach to moral reasoning through two key ways, in which religious ethics: (a) proposes that there exists a harmonization between faith and human reason to chase the ideals of love and sense to others; and (b) maintains a distinctive worldview or end. It is also argued that satisfactorily ethics teaching will not be possible to reach without first engaging the religion-related questions about the nature of humankind (Muldoon, 1990) as it may provide an initial framework in helping students to distinguish between right and wrong (Bloodgood, Turnley, \& Mudrack, 2008). Besides, Sims and Felton (2006) have observed that when having discussions regarding business ethics, students often reflect values they absorbed as a child from, amongst others, their religious upbringing. Nonetheless, there is still a mixed result regarding the effect of religiosity on moral reasoning of accounting students (Hickman, 2013), in which the relationship is positive (Burks \& Sellani, 2008), negative (Ahmadi, Davoudi, Mardani, Ghazaei, \& ZareZadegan, 2013; Stapleton, 2013) or there is no relationship between them (Conroy \& Emerson, 2004; Hickman, 2013).

This current study addresses the issues by investigating the impact of integrating cultural and religious-based ethics concepts, named Tri Kaya Parisudha (TKP), into ethical training toward the moral judgment development of accounting students. TKP derived from the word Tri, which means three, Kaya, which means behavior and Parisudha, which means purity or spirituality (Rosalina, 2017). It means the Three Holy Deed, i.e., think good, speak good, and do good (which will be explained in greater detail 
in the next section of the paper). TKP is a form of religious values of Balinese people that has long been recognized as a reference in acting and behaving ethically in everyday life (Kepramareni, Sudarma, Irianto, \& Rahman, 2014; Swardhana, Jaya, \& Kartika, 2015). In the context of higher education, Burks and Sellani (2008) have found the significantly positive effect of taking religion courses on the business students' level of moral reasoning. Also, the recent work of Sofyani and Rahma (2015) has proved that Indonesian economics students who had prior participation in a religious values-based character education behaved more ethically in preparing financial statements than those who had not. Both Burks and Sellani and Sofyani and Rahma gave treatments of religious value and business ethics course at a different time, and each of them is managed as a stand-alone intervention.

In contrast to those projects that separate between the instilment of religious values and business ethics courses, we prefer to integrate them. We followed Bloodgood et al. (2008) and Cassidy (2006), who suggested that the integration learning method can be considered as a better way to instill a more contextual understanding of business ethics. The results of this study are expected to contribute to the development of academic studies on Tri Kaya Parisudha and its integration to ethical learning on the development of students' morality. Besides, the results of the study are expected to be used as a consideration for business ethics lecturers in universities to integrate local wisdom and religiosity values into ethical learning to improve students' morality.

The rest of the paper is organized as follows. In the next section, a review of the literature and research hypothesis development is given, followed by a general description of our used method. The last two parts then provide results and discussions as well as the conclusion, limitations, and suggestions for future research.

\section{Literature Review and Hypothesis Development}

Every individual has different levels of morality. This difference causes the individual to solve an ethical problem differently. In other words, the level of morality of an individual can be measured by looking at their responses in dealing with cases related to ethical dilemmas. One theory that attempts to explain the morality of a person is the theory of cognitive moral development (from now on, CMD) developed by Lawrence Kohlberg in 1971. This theory assumes that every individual experiences moral development through several levels along with individuals' increasing age (Killen \& Smetana, 2015). Also, Kohlberg's CMD theory focuses on cognitive processes involving moral judgment, as well as linking moral judgments to ethical actions. The theory of CMD stems from Kohlberg's critique of socialization theory and behaviorism, which ignores the moral process of the child. He argues that imitation and observation alone are not enough for a child to understand the concepts of justice, fairness, and the happiness of others. He also assumes that often, adults who are subjected to imitation and observation by children have low morality. This phenomenon raises a question about how a child who does not have an excellent example for him/herself can form an excellent moral 
judgment. Therefore, this theory assumes that the changes in individual ages will affect the level of morality of the individual.

Based on the theory of CMD, there are three levels in the development of individual morality, such as pre-conventional level (level I), conventional level (level II), and postconventional level (level III) (O'Flaherty \& Gleeson, 2016). Each level consists of two stages of development that reflects the level of individual morality when faced with an ethical dilemma. The higher the level or stage of an individual's cognitive moral development, the better the quality of moral judgments that an individual possessed. According to Kohlberg (1971), the levels of an individual's cognitive moral development conceptualized in the theory of CMD are as follows:

\section{Level I (Pre-Conventional)}

At this level, an individual acts and judges the righteousness of action based on reward and punishment. This level can be divided into two stages:

a) Stage 1: Orientation on punishment; consequences or physical punishment of an effort determines the moral judgment of an individual. In other words, the righteousness of an action is judged based on the results (or punishment) of the work.

b) Stage 2: The instrumental relativist orientation; at this stage, the individual judges that a right action is an action that can bring positive benefits to him/herself, and sometimes to the others. At this stage, there is an element of justice, reciprocity, and equality, but it is always interpreted physically and pragmatically.

\section{Level II (Conventional)}

At this level, the individual engages in moral action solely to satisfy the expectations of his/her family and social group, regardless of the consequences of his/her actions. This level can be divided into two stages:

a) Stage 3: Good boy/nice girl orientation; individual judges that the right action is an action that can benefit other individuals. They act by the expectations and desires of other individuals to be viewed as good children by others.

b) Stage 4: Law and authority orientation; at this stage, an individual's actions are oriented to the laws prevailing in his/her environment, and assume that a right action is an action that conforms to the law and authority.

\section{Level III (Post-Conventional)}

At this level, an individual has been able to identify and realize the correct values and moral principles. This level can be divided into two stages:

a) Stage 5: Social contract orientation; at this stage, an action is deemed correct if it conforms to individual rights and standards that have been previously critically 
analyzed and agreed upon by its social environment. In other words, an individual's judgment of an action is based on personal values, rather than on constitutionally accepted standards.

b) Stage 6: Universal ethical principles orientation; at this stage, the righteousness of an action is judged based on the logical, universal, and consistent moral principle using an individual's conscience. Individual emphasizes universal ethical principles such as justice, reciprocity, equality of human rights, and respect for the dignity of other individuals.

Some researchers have attempted to relate religiosity and the degree of morality based on the theory of CMD. Ahmadi et al. (2013) investigated the relationship between moral development, religiosity, and religious orientation of students at a university in Iran. The results showed that moral development negatively affected individual religiosity. In other words, the higher the level of individual morality, the lower the individual's intention in applying his religious obligations.

On the other hand, Hickman (2013) found that universities based on religion and individuals' religiosity could not increase moral reasoning. This finding is following research by Conroy and Emerson (2004), who found that the level of individuals' religiosity did not influence morality. Stapleton (2013) also found the same result in which individuals categorized as unreligious showed a higher level of moral reasoning than individuals who were classified as religious. Also, Herlyana, Sujana, and Prayudi (2018) found that the students' level of religiosity harmed their academic fraud behavior.

The results of those studies might contradict the views of people in general that religious individuals will exhibit higher morality than non-religious individuals. However, Stapleton (2013) asserted that the results of those studies do not necessarily indicate that religious individuals have low moral reasoning, yet they may have different perspectives in making ethical decisions. According to, Graafland (2017) religious individuals try to keep their behavior to be matched to their religion's identity. In other words, religious individuals' behavior will always be based on the rules taught in their belief to still attach their religiosity identity into themselves. Related to the theory of $C M D$, it refers to the characteristics of individuals on the current level in which their actions are based on the fulfillment of expectations of other individuals and rules or laws (Kohlberg, 1971). It is presumed then to be the cause that religious individuals tend to be at the general level in the level of Kohlberg's CMD theory (Stapleton, 2013).

Tri Kaya Parisudha (TKP) is a form of religious values of Balinese people that has long been recognized as a reference in acting and behaving ethically in everyday life (Kepramareni et al., 2014; Swardhana et al., 2015). It is embodied in Holy Hindu scripture, Sarasamuscaya, written by Bhagawan Wararuci, a hermit-manganese from the island of Java at around the 9th century. TKP is derived from the word Tri, which means three, Kaya, which means behavior and Parisudha, which means purity or spirituality (Rosalina, 2017). It means the Three Holy Deed, i.e., think good, speak good, and do good. TKP is a technique of self-control, and a means to fulfill the individual obligation of 
mental and spiritual purification to "solve" the specific Hindu problem of life (circle of rebirth, reincarnation, and karma) (Landmann, 2010).

TKP has an origin from the beliefs of the essence of the Law of Karma Phala (karma means deed, phala means result)-good deeds will result in good, bad deeds will result in evil (Krishna, 2010). Accordingly, Pratiwi (2016) contends that one's ability to control the mind, speech, and behavior can make people be able to avoid unwanted things happen in his/her life. On Sarasamuscaya, it is said that there are ten forms of lust control behavior, that is, three for mind control (Manacika Parisudha), four for speech control (Wacika Parisudha), and three for behavior control (Kayika Parisudha). In detail, the components of TKP are as follows (Asmariani, 2012; Wariati, 2016):

\section{Manacika Parisudha - The Sanctification of the Mind}

The values embedded in this conception guide a person to well organize his/her thoughts before speaking and taking action since it is acknowledged that the thought is the primary source of word and deed. There are three forms of implementation of Manacika Parisudha, as mentioned in Sarasamuscaya, that is:

a) Not wanting to have as well as feeling envy toward others belongings

b) Not being angry and rude to all beings

c) Believe in the law of Karma Phala (the doctrine of inevitable consequence)

\section{Wacika Parisudha - The Sanctification of the Speech}

It is believed that words are the root and origin of everything. Hence, dishonesty in words can be a reflection of dishonesty in all things. Also, if we often say dirty, rude, and abusive, it will lead us to enmity and sin. Conversely, if we always keep and control every word that comes out of our mouths, it will bring us to peace and happiness. There are four forms of implementation of Wacika Parisudha, as mentioned in Sarasamuscaya, that is:

a) Not speaking evil against one another

b) Not speaking angrily and rudely to another person

c) Not slandering another person

d) Not lying

\section{Kayika Parisudha - The Sanctification of the Behavior}

The good deeds are a real implementation of good thoughts and speeches. By doing something, people are said to have done karma, which can determine how one's future life is. Therefore, those who are realizing that all the karma they do may give them phala will always strive to do good to obtain a more enjoyable life in the future. There are three forms of implementation of Kayika Parisudha, as mentioned in Sarasamuscaya, that is: 
a) Not committing murder

b) Not doing steal

c) Not committing adultery

In some previous studies, TKP was found to have a strong correlation with individual or group behavior. Research conducted by Kepramareni et al. (2014) in nonprofit organizations in Bali, for example, implied that the implementation of TKP allows organizational elements to promote transparent and accountable behavior in managing the organization. The behaviors manifest within the organization are understood as a form of ethical behavior and derived from self-control in the way of consciousness always to maintain the purity of mind, which has consequences on the virtue of words and deeds (p.4: 4). In a different study, Swardhana et al. (2015) found that the aspects of Balinese local wisdom, including TKP, could become a more appropriate social control rather than the concepts of Western social control theory, in tackling the problem of juvenile delinquency behavior in the province of Bali.

\section{Business Ethics Course, Religiosity and Student's Moral Development}

Current business ethics courses have a learning goal to encourage students' ethical understanding and reasoning ability by sharpening their moral awareness as well as the capacity for moral judgment (Cassidy, 2006). It is also recognized that a business ethics course can provide not only practical ethical tools and techniques in promoting moral development and moral conflict management but also philosophical ideas in reflecting on the conditions and consequences of one's work (Brinkmann \& Peattie, 2005). Indeed, the business school should maintain an ethical perspective in its educational process because the end product of business decisions can profoundly influence the wealth allocation in society. For accounting students, a business ethics course plays a vital role in shaping students' behavior as a future business professional/accountant (TormoCarbó, Oltra, Seguí-Mas, \& Klimkiewicz, 2016) since ethical conduct is the essence of meaningful professional lives (Bean \& Bernardi, 2007).

Although most of the previous findings in the existing literature suggest that business ethics education have successful performance yields, there is also some evidence of poor outcomes of the business ethics course. Burks and Sellani (2008) examined whether ethical behavior influenced by the amount of ethical intervention received by students in the form of ethics classes. They found that no significant differences existed in students' moral values between those who were taking an ethics course and those who were not. Also, Mayhew and Murphy (2009) have concluded that ethics education alone may not be enough to improve ethical behavior. The experimental setting they organized proved that conventional ethics education resulted in, unfortunately, introjected rather than integrated ethical values. Recently, Tormo-Carbó et al. (2016) observed that the impact of specific business ethics courses on students' ethical awareness was questionable. Their findings, strangely enough, indicated higher ethics awareness among students who had not taken ethics courses. 
Tormo-Carbó et al. (2016) considered the extent to which the poor design, content, or implementation of ethics course that might be the cause of unexpected findings of their study. Likewise, many scholars also agreed that it is the methodologies employed in a business ethics course that plays an essential role in running business ethics education if it wants to be successful. Cassidy (2006) and McCann (1997) straightforwardly suggested considering a student's religious experience when teaching ethics to yield a significant and lasting impact on students' moral judgment. The McCann's and Cassidy's notions of the critical role of religious aspect on students' moral judgment are in line with the results of Burks and Sellani (2008) and Sofyani and Rahma (2015) that indicated the positive relationship between religiosity and moral judgment/behavior of business students. Burks and Sellani (2008) emphasized the existence of a higher calling acceptance in an individual's life that may explain how religiosity can be related to students' moral judgment. They asserted that while some religions follow strict adherence to rules, others are more principles-based. It will thus make a difference in a person's ethical values. Meanwhile, Sofyani and Rahma (2015) contended that religious values are the real aspect underlies someone's behavior, including in-context economy and business. In their experiment, they were instilling the Islamic religious character concerning the entire and whole existence of God, full compliance with and obedience to religious teachings, and doing good and full of responsibility. We, therefore, expect that by integrating ethical intervention in a business course with a religious-based ethical concept, i.e., Tri Kaya Parisudha (TKP), the students' moral judgment can be significantly improved. Formally stated, the hypothesis of this research is:

$\boldsymbol{H}_{1}$ : Students who are receiving ethical training that integrates with Tri Kaya Parisudha (TKP) concept will exhibit higher moral judgment development than those who do not receive integrated ethical training.

\section{Research Method}

This research used Pre-test-Post-test Control Group experimental design to test the proposed hypothesis. In this design, the random allocation of subjects to a treatment or control condition is done, and the test scoring is conducted before and after the experimental manipulation (Dugard \& Todman, 1995). The cultural and religious-based ethics concept (Tri Kaya Parisudha-TKP) was used as the treatment in the experiments carried out to the students (ethics education with an emphasis on TKP and ethics education without emphasis on TKP).

Participants of the experiment were 46 undergraduate students of the Accounting Department in a large public university in Bali Province of Indonesia who were taking the Business and Professions Ethics course. They were allocated to a treatment or a control group in which the participants received two different scenarios. In the " $A$ " scenario, participants were given a course material of Business and Profession Ethics with the emphasis on the TKP principle. Meanwhile, in the " $B$ " scenario, participants were given course material of Business and Profession Ethics without stress on the TKP principle (Table I). Experimental treatments were not carried out between individuals in an 
experimental lab but between experimental classes. All students enrolled in Class I were given a course material of Business and Profession Ethics with the emphasis on the TKP principle (the " $A$ " scenario). While all students enrolled in Class II were given a course material of Business and Profession Ethics without the emphasis on the TKP principle (the " $\mathrm{B}$ " scenario). Inter-class experimental treatments were based on experiments conducted by Martinov-Bennie and Mladenovic (2015) to prevent students from becoming aware of the experimental treatments given.

Table 1 Experimental Design

\begin{tabular}{lcc}
\hline Experiment Group & \multicolumn{2}{c}{ Experiment Stage } \\
& Pre-Test & Post-Test \\
\hline Class I (with TKP/treatment) & 1 & 2 \\
Class II (without TKP/control) & 3 & 4 \\
\hline
\end{tabular}

Before the experiments were conducted, as a formal academic procedure took on each semester, students of the Business and Professions Ethics Course were randomly assigned into four classes by the department. Then, when the experiments were conducted, the participants were randomly assigned to either the experimental group or the control group. We used a simple randomization technique in which the participants were randomized based on a single sequence of random assignments (Suresh, 2011). The randomization is done by using computer-generated random numbers. Chi-square analysis revealed that there was no significant difference between the two groups concerning age and sex ( $p$-value $>0.05$ ); therefore, the randomization could be considered successful.

The testing of the instruments is done twice in each class. The students were not aware that the test would be conducted twice. The first test was a preliminary test (pre-test). The pre-test was to find out the description of the behavior of participants of each class when facing ethical cases. The pre-test was done before treatment in the experimental class. After conducting the first test, then the course material provided as usual in class II. For the class I, the course material was given with an emphasis on the concept of TKP. As in class II, participants were first given a conceptual understanding of the code of ethics for the professional accountant that serves as a requirement for a professional accountant in fulfilling his/her responsibility to act in the public interest. Its fundamental principles include the principle of integrity, objectivity, professional competence, and due care, confidentiality as well as professional behavior.

The treatment for class I's participants was given by integrating the TKP concept into the fundamental principles of the code of ethics for a professional accountant. For example, participants were encouraged that regarding the integrity principle that requires every Professional Accountant to be straightforward and honest in their entire professional and business relationships, the unwavering practice of the Kayika Parisudha (i.e., doing honest, ethical and righteous deeds) and the Wacika Parisudha (i.e., always tell the truth) would make sure that professional accountant met the requirement (see the Appendix). At the end of each treatment session, to ensure the effectiveness of the manipulation, participants were asked to answer the following question: "Is there a 
relationship between the fundamental principle of code of ethics for professional accountant and the concept of Tri Kaya Parisudha? If "yes," how is the relationship?".

The lecturing for each class was conducted for four months before performing further testing. During the experiment's implementation period, there were no discussions of the case given in the experimental task or other ethical cases outside the Business and Professional Ethics courses. The procedure was done to anticipate the existence of external factors that might influence the ethical principles of the students participating in the experiment. Therefore, the researchers strongly believe that the ethical principle in students was mainly influenced by Business and Professional Ethics experimental courses. The final test (post-test) then conducted to find out the description of the moral judgment of participants in dealing with ethical cases after the Business and Profession Ethics course ended for each class. This stage is a crucial step to see the development of the ethical judgment of participants during the Business and Profession Ethics course, especially for the treatment class (class I).

The research instrument used to obtain data from the participants is a Defining Issues Test (DIT) questionnaire devised by James Rest in 1974. DIT is the most commonly used method and has an essential role in the development of ethical research, especially in accounting and auditing (Bailey, Scott, \& Thoma, 2010). The measurement of morality through DIT is based on six levels of cognitive moral development proposed by Kohlberg. In the DIT, individuals are asked to provide judgments on some cases concerning ethical dilemmas. The score in DIT will depict the level of individuals' morality based on Kohlberg's CMD theory. The main focus of DIT is assessing the level of understanding and interpretation of individuals in ethical cases (Thoma \& Dong, 2014).

Furthermore, Christensen et al. (2016) argue that the DIT instrument captures the capacity of individuals' ethical judgments, but is unable to depict the capacity of individuals' ethical decision making. This characteristic has been previously confirmed by Bailey et al. (2010) that of the several components of morality, DIT merely assesses the moral judgment of the individual. Nevertheless, they suggest that research on students' moral reasoning and accounting profession should use DIT instruments because of their valid status despite criticism of DIT instruments.

In this study, the results of filling the DIT questionnaire were converted to a p-score. Pscore measures the level of individual morality based on Post-Conventional stages. In his theory, Kohlberg (1971) states that the Post-Conventional level represents the ability of individuals to identify and understand the value of truth and morality. Therefore, the results of the $p$-score in this study were expected to capture changes in the morality of students at the Post-Conventional level while attending the Business and Professional Ethics course.

Data collection was done by giving the research instrument to each student who acts as the participants of this study. The data collection steps used in this experiment are as follows: 
1. Research instruments were distributed to participants.

2. On the pre-test stage, participants were directed to read the case material, and were asked to respond to the given case.

3. After the pre-test was done, the lecturing of Business and Profession Ethics was done with different treatment:

a) For the class I (the class with emphasis on TKP), the course material was given by linking the material, and the ethical case studied with the concept of TKP.

b) For class II (the class without emphasis TKP), the course material was given as usual without a focus on the concept of TKP.

4. After the completion of the course materials, participants were asked to respond the same case as in the previous experiment. This stage is a post-test stage to see whether the treatment is successful in the experimental class.

Hypothesis testing was conducted using independent t-test analysis to test whether there were significant ethical differences between each class and also between pre-test and post-test at the significance level $(\alpha)$ of 0,05 . Before conducting an independent $t-$ test, some assumptions must be met, such as observation conducted between research group (in this case is experiment class) must be done independently, the dependent variable was normally distributed, and both research groups have the same variance (homogeneous) (Hair, Black, Babin, \& Anderson, 2010).

To ensure that research data are normally distributed and have the same variance (homogeneous), the data were tested using the Kolmogorov-Smirnov method for univariate normality and Levine's test for homogeneity of variances. After independent sample t-test and paired sample t-test were done, the experiment considered to be successful if it meets the following conditions:

1. There was no significant difference in students' morality (DIT p-score) in the pre-test results between Class I (with emphasis on the TKP principle) and class II (without emphasis on the TKP principle). This condition is to ensure that students have the same moral reasoning for each class before the experiment is conducted.

2. There is no significant difference in students' morality (DIT p-score) in the pre-test and post-test results in class II (without emphasis on the TKP principle). This requirement is to ensure that no factors are affecting the students' moral reasoning.

3. There is a significant difference in students' morality (DIT p-score) between the pretest and post-test results in class I (with emphasis on the TKP principle) (the level of students' morality in the final test is significantly higher than the initial test). This requirement is to ensure that the emphasis on the TKP principle can improve students' morality.

4. There is a significant difference in students' morality (DIT p-score) in post-test results between class I (with emphasis on the TKP principle) and class II (without emphasis on the TKP principle) (class I's morality is significantly higher than class II). This requirement is to ensure that the emphasis on the TKP principle in the Business and Profession Ethics course is a better method to improve students' morality than without emphasis on the principle of TKP. 


\section{Result and Discussion}

Table II shows the descriptive statistics of participants' DIT p-score. Recall that we are conducting a pre-test-post-test control group experimental design in which a dependent variable i.e. moral judgment (DIT p-score), is scored on a test before and after the experimental manipulation i.e. giving a business ethics course that integrated with the conception of TKP. Based on the data in Table II, the average participants' DIT p-score at the pre-test stage is 13.62 for the treatment group, and 18.41 for the non-treatment group. The median for the overall DIT p-score at the pre-test stage is 17 . Using median split, which is a valid and robust method to be used in intergroup difference testing (lacobucci, Posavac, Kardes, Schneider, \& Popovich, 2015), it can be interpreted that the level of morality of participants in the treatment group is low (the DIT p-score is smaller than median score), while the level of morality of participants in the non-treatment group is high (the DIT p-score is higher than median score).

For the post-test stage, the average participants' DIT p-score is 26.30 for the treatment group, and 20 for the non-treatment group. The median for the overall DIT $p$-score at the post-test stage is 20 . By using the median split method, it can be interpreted that the level of morality of participants both in the treatment and the non-treatment group is high (the DIT p-score is greater or equal to the median).

In addition, in consideration to the Table II we can observe that participants in treatment group have higher DIT p-score at post-test (mean $=26.30 ;$ SD $=10.403$; high morality) than at pre-test (mean $=13.62$; $\mathrm{SD}=8.815$; low morality). It is also can be found that the DIT p-score of participants in treatment group are higher (mean $=26.30$; $S D=10.403$; high morality) than in control group (mean $=20.00 ; S D=9.101 ;$ high morality) at post-test. We, therefore, may expect that the treatment given is empirically making a difference in which it improves the level of moral judgment of participants. However, it must also be noticed from Table II that the control group participants' DIT pscore at the pre-test is higher (lower) in comparison with the DIT p-score of participants in the treatment group at pre-test (DIT p-score of participants in the control group at post-test). These results will be further analyzed in the following part.

Table 2 Descriptive Statistics of DIT P-Score

\begin{tabular}{llcc}
\hline & \multicolumn{2}{c}{ Experimental Stage } \\
\hline Experimental & Treatment & Pre-Test & Post-Test \\
Group & (with integrated TKP) & $M=13.62$ & $M=26.30$ \\
& & $S D=8.815$ & $S D=10.403$ \\
& Non-Treatment & $n=23$ & $n=23$ \\
& (without integrated TKP) & $M=18.41$ & $M=20.00$ \\
& & $S D=10.535$ & $S D=9.101$ \\
& $n=23$ & $n=23$ \\
\hline
\end{tabular}

$\mathrm{M}=$ mean, $\mathrm{SD}=$ standard deviation, $\mathrm{n}=$ number of participants in the cell

To determine the significance of the difference of students' moral judgment between experimental stages and groups, we utilized the Paired Sample t-test and Independent Sample t-test statistical analysis, respectively. The results are shown in Table III Panel A, 
$B$ and Table IV panels A and B. There is a difference between participants in the treatment group and control group on their DIT $p$-score at pre-test, yet insignificant ( $p$ value $=0.102$ )

Table 3 Independent Sample t-test of DIT p-score between Experimental Groups

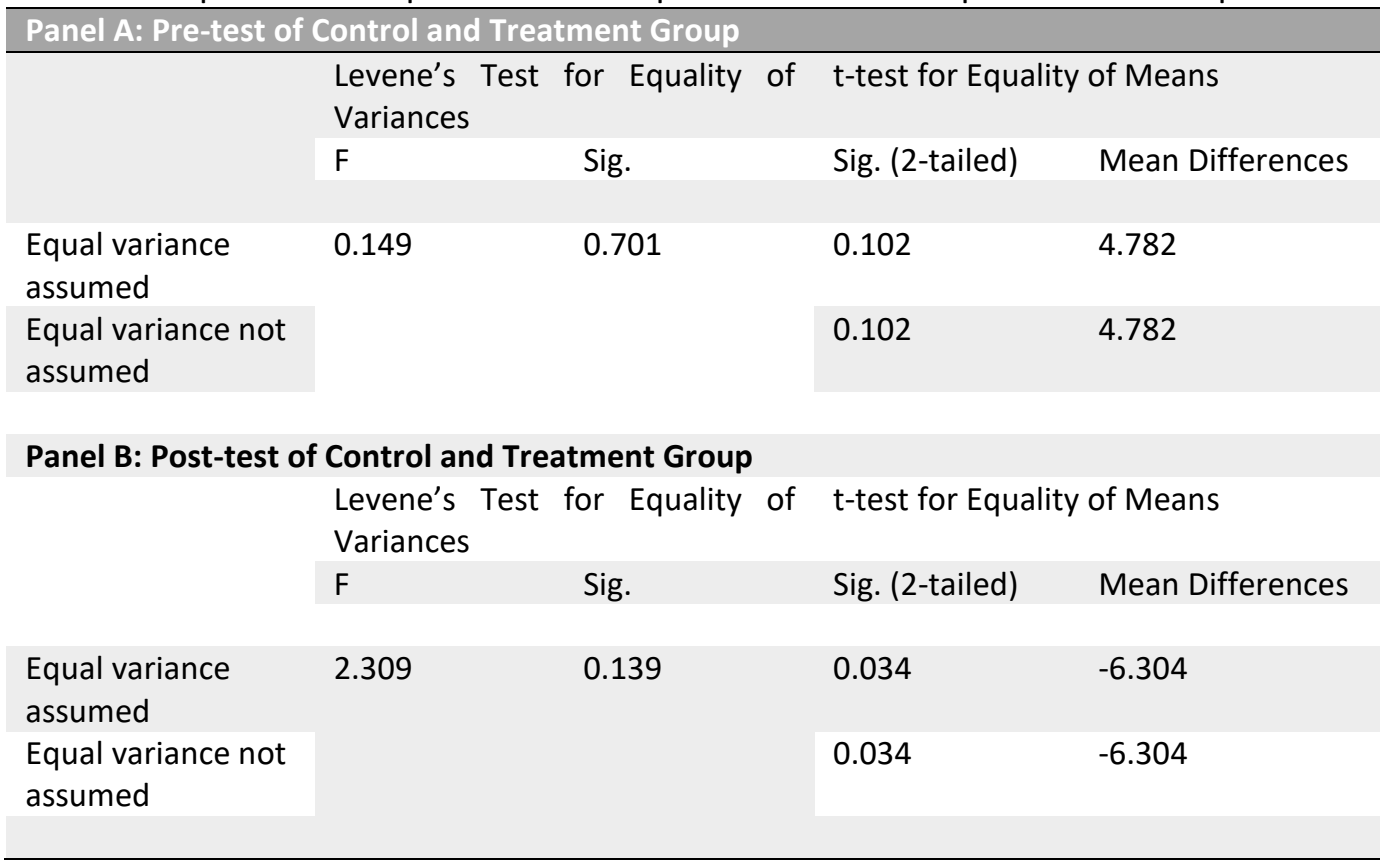

It also can be observed that the difference of participants' DIT p-score in the control group between pre-test and post-test is insignificant ( $p$-value $=0.607)$. Meanwhile, a significantly difference of DIT $p$-score are appeared on participants in treatment group between pre-test and post-test at $\alpha=0.01$ ( $p$-value $=0.000)$ in which post-test score is higher than the pre-test one as well as between treatment group and control group at post-test at $\alpha=0.05$ ( $p$-value $=0.034$ ) in which treatment group's score is higher than the control one. Therefore, it can be concluded that our research hypothesis is empirically supported.

Table 4 Paired Sample t-test of DIT p-score between Experimental Stage

\begin{tabular}{|c|c|c|c|c|}
\hline & \multicolumn{4}{|c|}{ Paired Differences } \\
\hline & Mean & Std. Deviation & $\mathrm{t}$ & Sig. (2-tailed) \\
\hline \multicolumn{5}{|l|}{ Pair 1} \\
\hline Control Pretest & \multirow[t]{2}{*}{-1.594} & \multirow[t]{2}{*}{14.664} & \multirow[t]{2}{*}{-5.21} & \multirow[t]{2}{*}{0.607} \\
\hline Control Posttest & & & & \\
\hline \multicolumn{5}{|c|}{ Panel B: Pre-test and Post-test of Treatment Group } \\
\hline & \multicolumn{4}{|c|}{ Paired Differences } \\
\hline & Mean & Std. Deviation & $\mathrm{t}$ & Sig. (2-tailed) \\
\hline \multicolumn{5}{|l|}{ Pair 1} \\
\hline Treatment Pretest & \multirow[t]{2}{*}{-12.680} & \multirow[t]{2}{*}{12.687} & \multirow[t]{2}{*}{-4.793} & \multirow[t]{2}{*}{0.000} \\
\hline Treatment Posttest & & & & \\
\hline
\end{tabular}


As provided in the previous part, the results indicated that business ethics education based on local wisdom, in this case, is Tri Kaya Parisudha, which can increase students' moral reasoning. Tri Kaya Parisudha is one of the most important aspects of Balinese culture. Tri Kaya Parisudha is one part of Hinduism's teachings that bring value to the human being. According to Tri Kaya Parisudha, the truth or Dharma can be attained by a man by preserving the sanctity of the three elements, namely thoughts, words, and deeds.

The emphasis of Tri Kaya Parisudha is very relevant to be applied in the Business and Profession Ethics course. This result is in line with the research finding conducted by Cassidy (2006), Burks and Sellani (2008) and Sofyani and Rahma (2015) that religiosity can improve students' moral reasoning. In this study, before the experiment was conducted, students in the treatment group had low post-conventional morality. In other words, students have not been fully able to identify and understand the actual values and moral principles. However, this study found that integration of TKP in the learning process of Business Ethics and Professionals could improve the postconventional morality of students, proven by post-test DIT p-score that shows a high level of morality. Even though the p-score at the post-test stage for both treatment and non-treatment groups is equally high, the DIT p-score for the treatment group is significantly higher. Thus, this study proved that the emphasis of Tri Kaya Parisudha in business ethics education can increase student's moral reasoning level at the postconventional stage significantly compared to ethics education without the emphasis of Tri Kaya Parisudha.

Students generally have religious knowledge within themselves. However, such knowledge is rarely attributed to lecture material that teaches about moral behavior; in this case, it is Business and Profession Ethics. The business and Profession Ethics course that is given to the students can increase the students' moral reasoning level, but this research shows that the increase is not significant. But, the significant rise in students' moral reasoning is shown in the class with the emphasis of Tri Kaya Parisudha. The emphasis of Tri Kaya Parisudha is allegedly able to awaken the students' memory on the religious knowledge that they have so far so that students use that knowledge when faced with an ethical case. Therefore, students that have been exposed to Tri Kaya Parisudha show higher ethical reasoning than students without the exposure of Tri Kaya Parisudha.

\section{Conclusion}

From the results of this study, it can be concluded that ethical education with an emphasis on Tri Kaya Parisudha has its potential is more able to improve students' moral reasoning than ethical education without the emphasis of Tri Kaya Parisudha. In other words, ethical education, especially at the college level, will be more effective if the aspect of religiosity is included within the education process. Although this research supports the proposed hypothesis, there are some disadvantages to this study. First, this study uses an experimental method using cases that didn't reflect the actual condition. 
Besides, the cases used in this study have not been sufficiently related to ethical cases occurring in the business world. Future research is expected to use ethical cases related to business activities so that it is more relevant to be used in the Business and Profession Ethics course.

Secondly, this study only measures the moral judgment of the students. In other words, this research has not been able to fully capture the influence of Tri Kaya Parisudha on students' behavior. Further research is expected to examine the impact of ethical education based on religiosity aspects on students' moral judgment and behavior so that it can show the effectiveness of ethics education based on religious elements as a whole. Thirdly, this research didn't consider another demographic variable that could affect moral judgment, such as the participant's ability to learn or participants' behavioral traits. Future research should consider other variables that could affect a student's moral judgment.

\section{References}

Adkins, N., \& Radtke, R. R. (2004). Students' and Faculty Members' Perceptions of the Importance of Business Ethics and Accounting Ethics Education: Is There an Expectations Gap? Journal of Business Ethics, 51(3), 279-300. https://doi.org/10.1023/b:busi.0000032700.07607.02

Ahmadi, V., Davoudi, I., Mardani, M., Ghazaei, M., \& ZareZadegan, B. (2013). The Relationships Among Moral Development, Religiosity and Religious Orientation in Students. Procedia - Social and Behavioral Sciences, 84, 674-678. https://doi.org/10.1016/j.sbspro.2013.06.624

Aini, N., Prayudi, M. A., \& Diatmika, P. G. (2018). Pengaruh Perspektif Fraud Diamond terhadap Kecenderungan Terjadinya Kecurangan (Fraud) dalam Pengelolaan Keuangan Desa (Studi Empiris ada Desa di Kabupaten Lombok Timur). Jimat (Jurnal Ilmiah Mahasiswa Akuntansi) Undiksha, 8(2), 1-13.

Andriana, D., \& Widaningsih, M. (2014). Kajian Integritas Akuntan Publik dan Akuntan Pemerintah dalam Transaksi Opini Audit. In dke. Frita Lussie Bramanti (Ed.), Seminar Nasional Ekonomi dan Bisnis (SNEB) 2014 (pp. 169-176). Bandung: Arpanji Pub.

Asmariani, A. A. R. (2012). Tri Kaya Parisudha Sebagai Kontrol Sosial Perilaku Remaja dalam Kehidupan Bermasyarakat di Era Globalisasi dan Modernisasi. Sphatika Jurnal Teologi, 6(1), 1-16.

Bailey, C. D., Scott, I., \& Thoma, S. J. (2010). Revitalizing accounting ethics research in the Neo-Kohlbergian framework: Putting the DIT into perspective. Behavioral Research in Accounting, 22(2), 1-26. https://doi.org/10.2308/bria.2010.22.2.1

Bean, D. F., \& Bernardi, R. A. (2007). A Proposed Structure for an Accounting Ethics Course. Journal of Business Ethics Education, 4, 27-54.

Bloodgood, J. M., Turnley, W. H., \& Mudrack, P. (2008). The influence of ethics instruction, religiosity, and intelligence on cheating behavior. Journal of Business Ethics, 82(3), 557571. https://doi.org/10.1007/s10551-007-9576-0

Brinkmann, J., \& Peattie, K. (2005). Exploring Business School Ethics. Journal of Business Ethics Education, 2(2), 151-170. https://doi.org/10.5840/jbee20052212

Burks, B. D., \& Sellani, R. J. (2008). Ethics, Religiosity, and Moral Development of Business Students. Journal of Leadership, Accountability and Ethics, Fall, 49-70. https://doi.org/10.1023/B:BUSI.0000025040.41263.09 
Cameron, R. A., \& O’Leary, C. (2015). Improving Ethical Attitudes or Simply Teaching Ethical Codes? The Reality of Accounting Ethics Education. Accounting Education, 24(4), 275-290. https://doi.org/10.1080/09639284.2015.1036893

Cassidy, J. C. (2006). A Pedagogy for Integrating Catholic Social Ethics into the Business Ethics Course. Journal of Business Ethics Education, 3, 35-54. https://doi.org/10.5840/ibee200633

Christensen, A., Cote, J., \& Latham, C. (2016). Insights Regarding the Applicability of the Defining Issues Test to Advance Ethics Research with Accounting Students: A Metaanalytic Review. Journal of Business Ethics, 133(1), 141-163. https://doi.org/10.1007/s10551-014-2349-7

Christensen, D., Barnes, J., \& Rees, D. (2007). Developing Resolve To Have Moral Courage: A Field Comparison Of Teaching Methods. Journal of Business Ethics Education, 4, 79_ 96. https://doi.org/10.5840/ibee200745

Conroy, S. J., \& Emerson, T. L. N. (2004). Business Ethics and Religion: Religiosity as a Predictor of Ethical Awareness among Students. Journal of Business Ethics, 5(4), 383 396. https://doi.org/10.1023/B:BUSI.0000025040.41263.09

Dellaportas, S., Jackling, B., Leung, P., \& Cooper, B. J. (2011). Developing an Ethics Education Framework for Accounting. Journal of Business Ethics Education, 8, 63-82.

Dugard, P., \& Todman, J. (1995). Analysis of Pre-test-Post-test Control Group Designs in Educational Research. Educational Psychology: An International Journal of Experimental Educational Psychology, 15(2), 181-198. https://doi.org/10.1080/0144341950150207

Epstein, E. M. (2002). Religion and business - The critical role of religious traditions in management education. Journal of Business Ethics, 38(1-2), 91-96. https://doi.org/10.1023/A:1015712827640

Floyd, L. A., Xu, F., Atkins, R., \& Caldwell, C. (2013). Ethical Outcomes and Business Ethics: Toward Improving Business Ethics Education. Journal of Business Ethics, 117, 753-776. https://doi.org/10.1007/s10551-013-1717-z

Graafland, J. (2017). Religiosity, Attitude, and the Demand for Socially Responsible Products. Journal of Business Ethics, 144, 121-138. https://doi.org/10.1007/s10551015-2796-9

Hair, J. F., Black, W. C., Babin, B. J., \& Anderson, R. E. (2010). Multivariate Data Analysis: A Global Perspective ( 7 th ed.). New Jersey: Pearson Education, Inc.

Herlyana, M. V., Sujana, S. E. E., \& Prayudi, M. A. (2018). Pengaruh Religiusitas dan Spiritualitas terhadap Kecurangan Akademik Mahasiswa (Studi Empiris pada Mahasiswa Universitas Pendidikan Ganesha dan Sekolah Tinggi Keguruan dan Ilmu Pendidikan Agama Hindu Singaraja). Jimat (Jurnal Ilmiah Mahasiswa Akuntansi) Undiksha, 8(2).

Hickman, M. S. (2013). Ethical Reasoning of Accounting Students: Does Religiosity Matter? International Journal of Business and Social Science, 4(6), 44-50.

Iacobucci, D., Posavac, S. S., Kardes, F. R., Schneider, M. J., \& Popovich, D. L. (2015). The median split: Robust, refined, and revived. Journal of Consumer Psychology, 25(4), 690704. https://doi.org/10.1016/j.jcps.2015.06.014

Kepramareni, P., Sudarma, M., Irianto, G., \& Rahman, A. F. (2014). Sekala and Niskala Accountability practices in the clan-based organization MGPSSR in Bali, Indonesia. Scientific Research Journal (SCIRJ), 2(2), 1-5.

Killen, M., \& Smetana, J. G. (2015). Origins and Development of Morality. In R. M. Lerner (Ed.), Handbook of Child Psychology and Developmental Science (7th ed., Vol. 3, pp. 701-749). New Jersey: John Wiley \& Sons, Inc.

Kohlberg, L. (1971). Stages of Moral Development. Moral Education, 1, $23-92$. 
Krishna, A. (2010). The Wisdom of Bali: The Sacred Science of Creating Heaven on Earth (A. McKee, Ed.). Jakarta: Gramedia Pustaka Utama.

Landmann, A. (2010). Hindu Class and Hindu Education System in Bali: Emergence, Organization, and Conception in the Context of Indonesian Educational and Religious Policies. Universität Frankfurt am Main, Germany.

Martinov-Bennie, N., \& Mladenovic, R. (2015). Investigation of the Impact of an Ethical Framework and an Integrated Ethics Education on Accounting Students' Ethical Sensitivity and Judgment. Journal of Business Ethics, 127(1), 189-203.

Mayhew, B. W., \& Murphy, P. R. (2009). The Impact of Ethics Education on Reporting Behavior. Journal of Business Ethics, 86, 397-416. https://doi.org/10.1007/s10551-0089854-5

McCann, D. P. (1997). Catholic Social Teaching in an Era of Economic Globalization: A Resource for Business Ethic. Business Ethics Quarterly, 7(2), 57-70. https://doi.org/https://doi.org/10.2307/3857298

Muldoon, M. (1990). Religious Studies and the Teaching of Business Ethics. McGill Journal of Education, 25(2), 245-253.

O’Flaherty, J., \& Gleeson, J. (2016). Irish Student Teachers' Levels of Moral Reasoning: Context, Comparisons, and Contributing Influences. Teachers and Teaching, 23(1), 5977. https://doi.org/10.1080/13540602.2016.1203777

Pratiwi, N. P. N. (2016). Ajaran Hindu dan Pembentukan Karakter: Implementasi Ajaran Kesusilaan Hindu dalam Membentuk Perspektif Logis dan Karakter Agamais Manusia Hindu pada Era Global. In S. A. Dr. I Ketut Sudarsana M.Pd.H (Ed.), Seminar Nasional Agama dan Budaya (Semaya II). Institut HIndu Dharma Negeri - Denpasar: Jayapangus Press.

Rosalina, P. D. (2017). The Implementation of Hindu Philosophy "Tri Kaya Parisudha” For Sustainable Tourism in Munduk Village, North Bali. Jumpa, 3(2), 223-237. https://doi.org/https://doi.org/10.24843/JUMPA.2017.v03.i02.p02

Saat, M. M., Porter, S., \& Woodbine, G. (2009). Does Religiosity Influence Ethical Sensitivity? An Investigation on Malaysian Future Accountants. Malaysian Accounting Review, 8(2), 7-41. https://doi.org/http://dx.doi.org/10.24191/mar.v8i2.254

Sims, R. R., \& Felton, E. L. (2006). Designing and Delivering Business Ethics Teaching and Learning. Journal of Business Ethics, 63, 297-312. https://doi.org/10.1007/s10551-0053562-1

Sofyani, H., \& Rahma, N. (2015). Pengaruh Pendidikan Karakter Keagamaan dan Otoritas Atasan untuk Berbuat Curang terhadap Perilaku Tidak Etis Akuntan. Jurnal Akuntansi dan Keuangan Indonesia, 12(2), 106-122. https://doi.org/http://dx.doi.org/10.21002/jaki.2015.07

Stapleton, M. (2013). An Investigation of Moral Development: the Effect of Religiosity on Kohlbergian Moral Reasoning. Student Psychology Journal, IV, 1-14.

Suresh, K. P. (2011). An Overview of Randomization Techniques: An Unbiased Assessment of Outcome in Clinical Research. Journal of Human Reproductive Science, 4(1), 8-11. https://doi.org/10.4103/0974-1208.82352

Swardhana, G. M., Jaya, I. B. S. D., \& Kartika, I. G. A. P. (2015). Kebijakan Kriminal dalam Penanggulangan Tindak Pidana dan Kenakalan Siswa SMA: Suatu Kajian tentang Penerapan Teori Kontrol Sosial dan Kearifan Lokal di Bali. Jurnal Magister Hukum Udayana, 4(1), 28-47.

https://doi.org/https://doi.org/10.24843/JMHU.2015.v04.i01.p02

Thoma, S. J., \& Dong, Y. (2014). The Defining Issues Test of Moral Judgment Development. Behavioral Development Bulletin, 19(3), 55-61. https://doi.org/10.1037/h0100590 
Thomson, J. (2014). The Challenges of Training Accountants for Government Work. Retrieved from http://www.forbes.com/sites/jeffthomson/2014/12/03/thechallenges-of-training-accountants-for-government-work/\#67a6fd457967

Tormo-Carbó, G., Oltra, V., Seguí-Mas, E., \& Klimkiewicz, K. (2016). How Effective Are Business Ethics/CSR Courses in Higher Education? Procedia - Social and Behavioral Sciences, 228, 567-574. https://doi.org/https://doi.org/10.1016/j.sbspro.2016.07.087

Wariati, N. L. G. (2016). Tri Kaya Parisudha Based Education in The Family. Dharma Acarya Faculty International Seminar, 1, 196-202. Denpasar - Bali: Jayapangus Press.

Warnell, J. M. (2010). An Undergraduate Business Ethics Curriculum: Learning and Moral Development Outcomes. Journal of Business Ethics Education, 7, 63-84.

https://doi.org/10.5840/ibee201075 